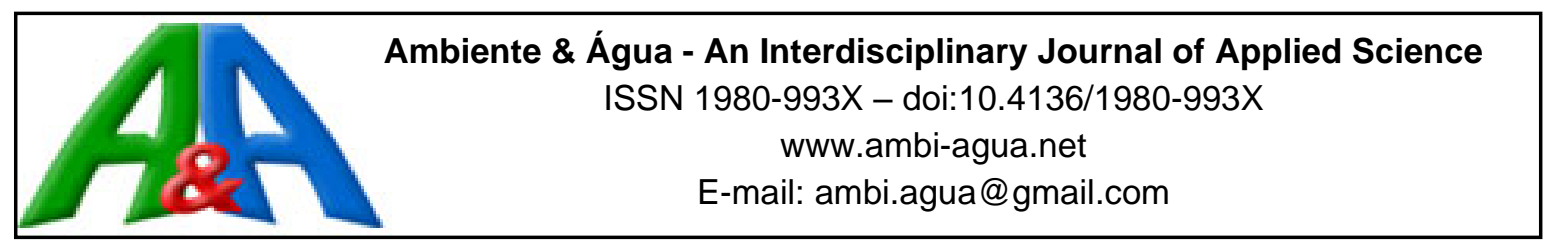

\title{
Cyanobacteria bloom variations and atmospheric variables, an environmental health contribution
}

\author{
ARTICLES doi:10.4136/ambi-agua.2523
}

Received: 28 Jan. 2020; Accepted: 08 Jun. 2020

\author{
Sofia Lizarralde Oliver $^{1 *}$; Priscilla Venâncio Ikefuti $^{2}$; Helena Ribeiro ${ }^{1}$ (D) \\ ${ }^{1}$ Departamento de Saúde Ambiental. Faculdade de Saúde Pública. Universidade de São Paulo (USP), Avenida \\ Dr. Arnaldo, n715, CEP: 01246-904, São Paulo, SP, Brazil. E-mail: lena@usp.br \\ ${ }^{2}$ Faculdade de Saúde Pública. Departamento de Epidemiologia. Universidade de São Paulo (USP), Avenida Dr. \\ Arnaldo, n715, CEP: 01246-904, São Paulo, SP, Brazil. E-mail: priscilla.ikefuti@yahoo.com.br \\ *Corresponding author. E-mail: sofia.lizarralde@gmail.com
}

\begin{abstract}
Urbanization in river basins contributes to the anthropogenic eutrophication of their water bodies, leading to the proliferation of toxic algae such as cyanobacteria. There is a characteristic pattern of seasonality in algal blooms and cyanobacterial communities, although these algae may be present or even dominant for most of the year, causing practical problems associated with high cyanobacterial biomass and potential health threats. The increased concentration of toxins originating from these algae, cyanotoxins, in water-supply reservoirs puts the population at serious risk, since they are not removed by conventional treatment and filtration. This study analyzed possible associations between climate elements and cyanobacteria biomass in the Guarapiranga dam reservoir, located in the metropolitan region of São Paulo, Brazil. Meteorological variables were studied exclusively in relation to the cyanobacteria biomass, in order to perceive the influence of weather and climate in this complex system and to provide data for modeling future climate change scenarios. For this purpose, cyanobacteria count data were used for the period from 2010 to 2016, grouped by month, in addition to the atmospheric variables. The strongest correlation with the blooms was with Irradiation and Total Rainfall, explaining $30 \%$ of cases of the occurrence of cyanobacteria proliferation at the point of collection GU 101. Despite the notable influence of climatic seasonality on the algae blooms, this difference varies and is not homogeneous, depending on the location and the species studied.
\end{abstract}

Keywords: climate change, cyanobacteria, environmental health.

\section{Florações de cianobactérias e variáveis atmosféricas, uma contribuição no escopo da saúde ambiental}

\section{RESUMO}

A urbanização de bacias hidrográficas contribui para a eutrofização antropogênica dos corpos d'água, levando à proliferação de algas tóxicas como as cianobactérias. Há um padrão característico de sazonalidade nas florações de algas e das comunidades de cianobactérias, apesar destas algas estarem presentes, ou mesmo dominantes, na maior parte do ano, trazendo problemas práticos associados com a grande biomassa de cianobactérias e suas potenciais ameaças à saúde. O aumento de concentrações de toxinas originárias destas algas, as 
cianotoxinas, na água de reservatórios de abastecimento expõe a população a sérios riscos, uma vez que elas não são removidas por tratamento convencional ou filtragem. O principal objetivo deste estudo foi analisar as possíveis associações entre os elementos do clima e a biomassa de cianobactérias na represa Guarapiranga, localizada na Região Metropolitana de São Paulo, Brasil. A variáveis meteorológicas foram estudadas exclusivamente em relação à biomassa de cianobactérias, a fim de verificar a influência do tempo e do clima neste sistema complexo e prover dados para a modelagem para futuros cenários de mudanças climáticas. Com esse propósito, dados de contagem de cianobactérias, do período 2010 a 2016, agrupados por mês, foram usados em associação às variáveis atmosféricas. A irradiação e a pluviosidade total foram as variáveis que apresentaram as correlações mais fortes com as florações, explicando $30 \%$ dos casos de proliferação de cianobactérias no ponto de coleta GU 101. Apesar da notável influência da sazonalidade climática nas florações de algas, ela não é homogênea, dependendo da localização e da espécie estudada.

Palavras-chave: alteração climática, cianobactéria, saúde ambiental.

\section{INTRODUCTION}

Urbanization in river basins contributes to anthropogenic eutrophication of their waterbodies. The problem frequently stems from a lack of basic sanitary infrastructure in informal settlements, inadequate drainage, as well as inefficient industrial discharge treatment systems and agricultural water-runoff prevention. These dynamics trigger an increase in nutrient concentrations, such as nitrogen and phosphorus, in the bodies of water, causing an imbalance in the limnologic environment and facilitating blooms or blossoming of potentially toxic algae, cyanobacteria. The increase in the concentration of toxins originating from these algae, cyanotoxins, in the water supply puts the population at serious risk.

The cyanotoxins from these algae are harmful to humans and are difficult to remove from the water with conventional treatment. They are hydrosoluble and pass through conventional treatment systems, being resistant even to boiling, generating risks of poisoning for the population. The epidemiological outcomes of poisoning by cyanotoxins include gastrointestinal disorders, neuromuscular dysfunctions, allergic reactions, neoplasms, and even death (Azevedo, 1998). More recently, a study (Pedrosa et al., 2019) suggested that they might be a cofactor in most severe cases of congenital Zika syndrome. Cyanobacteria thus imply very serious risks for public health.

Cyanobacteria proliferation in water-supply reservoirs requires the application of special water purification techniques for removal, and the use of energetic oxidants such as ozone (Rapala et al., 2002), chlorine and potassium permanganate (Rodríguez et al., 2007), or ultrafiltration and nanofiltration (Teixeira et al., 2005; Gijsbertsen-Abrahamse et al., 2005), which increase the treatment and distribution workload and in many cases render these processes unviable.

When temperature, light and nutritional conditions are favorable, surface layers of freshand sea waters may see an increase in cyanobacteria (WHO, 2011). There is a standard seasonal characteristic to algae blooms and cyanobacteria communities; however, these algae can be present or even dormant throughout most of the year, causing practical problems associated with elevated cyanobacteria biomass and potential health threats through the increase in toxins (WHO, 1999). The proliferation of cyanobacteria in eutrophic environments mostly occurs during months in which the temperature of the water is around $22^{\circ} \mathrm{C}$ or warmer (Fonseca et al., 2010; Ribeiro, 2007). In freshwater environments, with basic $\mathrm{pH}$, temperatures between $15^{\circ} \mathrm{C}$ and $30^{\circ} \mathrm{C}$ and high concentrations of nitrogen and phosphorus, this microorganism experiences accelerated growth (Cavalcante et al., 2009). Increases in the density of cyanobacteria have also been observed during the rainy season, directly related to the increased availability of nutrients

Rev. Ambient. Água vol. 15 n. 4, e2523 - Taubaté 2020 
in this period (Oliver and Ribeiro, 2015). Nutrient availability is controlled not only by the artificial addition of chemical and organic compounds and elements, but also by external ecosystem factors, like wind, precipitation and incidental radiation (Esteves and Suzuki, 2011). There is a relationship between global warming and the proliferation of toxic algae throughout the world (Paerl and Huisman, 2008). The scientific literature thus identifies a series of factors that encourage the proliferation of cyanobacteria, principally the eutrophication of waters, given the important role that nutrients play in this process. Regarding the influence of climatic and meteorological factors, the literature highlights annual seasonality and global warming, without precisely identifying which elements are most important.

With the intention of contributing to predict bloom episodes and promote preventive actions, this study analyzed possible associations between climatic elements and the cyanobacteria biomass in the Guarapiranga dam reservoir, located in the metropolitan region of São Paulo, Brazil. While recognizing that there are other important elements that contribute to cyanobacteria biomass, this investigation focused exclusively on the correlation between cyanobacterial blooms and meteorological variables in order to determine the influence of weather and climate on this complex system. It is expected that the results can aid the construction of mathematical models to predict the abnormal proliferation of cyanobacteria under different climate-change scenarios.

\section{MATERIALS AND METHODS}

Located in the metropolitan region of São Paulo, in the State of São Paulo, Brazil, the Guarapiranga dam (Figure 1) retains a reservoir for potable water supply. The basin is situated in the southern region of the metropolitan area of São Paulo, between $23^{\circ} 20^{\prime}$ and $24^{\circ} 00^{\prime} \mathrm{S}$ latitude and $46^{\circ} 20^{\prime}$ and $46^{\circ} 50^{\prime} \mathrm{W}$ longitude, at an altitude of 760 meters above sea level. Its climate is typical of southeastern Brazil, transitioning between tropical climates, humid with a defined dry period, and permanently humid subtropical climates. Daily mean temperatures range from $14^{\circ} \mathrm{C}$ to $24^{\circ} \mathrm{C}$ in winter and $20^{\circ} \mathrm{C}$ to $29^{\circ} \mathrm{C}$ in summer, dry and wet seasons, respectively.

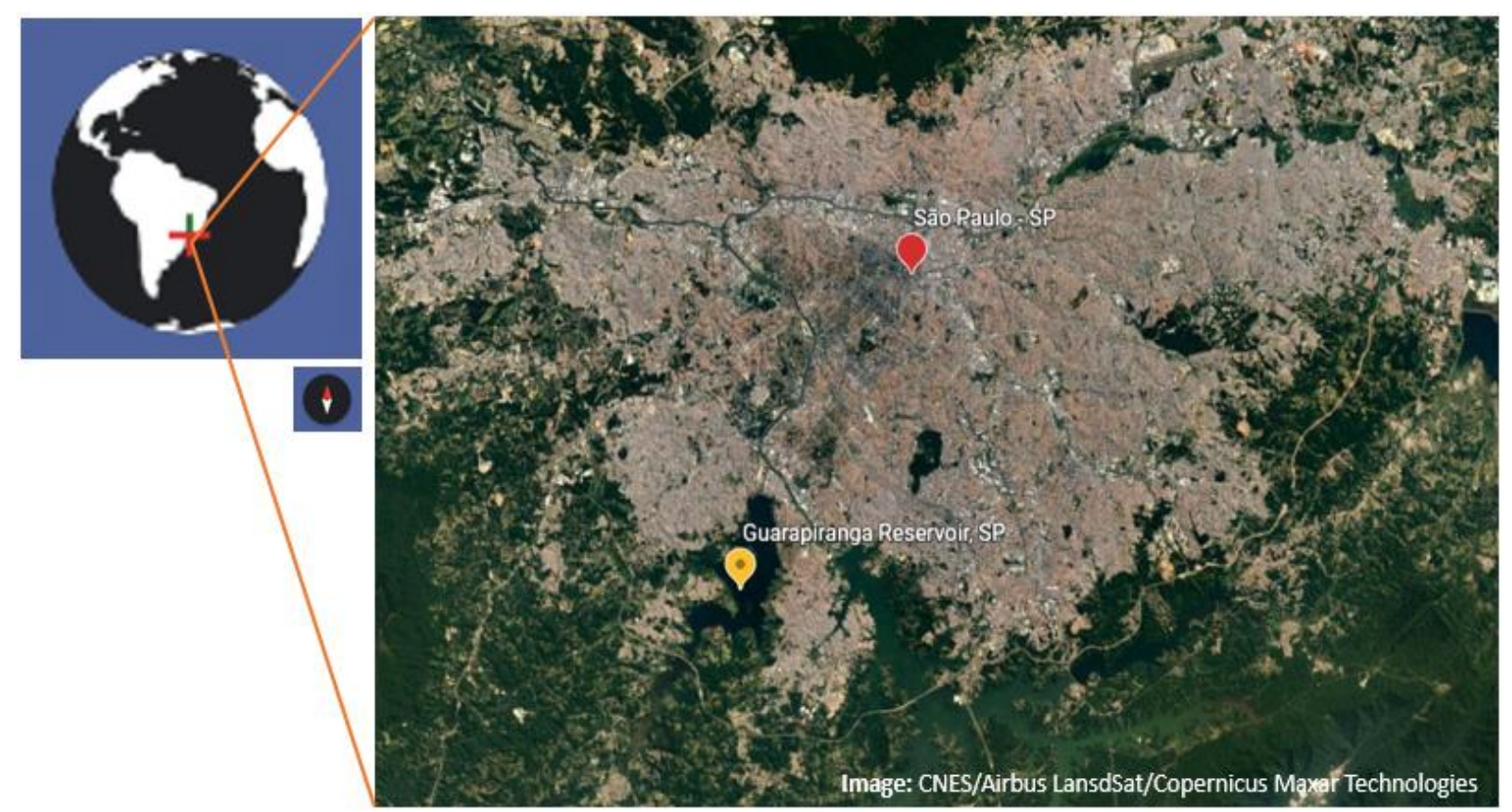

Figure 1. Guarapiranga Reservoir and the City of São Paulo - SP - Brazil in perspective.

Source: Adapted Image Mosaic (Google Earth Pro, 2020; CNES/LandSat/Copernicus Maxar Technologies).

The Guarapiranga dam retains a total reservoir area of $33.91 \mathrm{Km}^{2}$, with a depth of $5.7 \mathrm{~m}$ 
(Lamparelli et al., 2014). According to the Basic Sanitary Company of the State of São Paulo (Companhia de Saneamento Básico do Estado de São Paulo - SABESP), about 14 thousand liters of water per second flow through the dam, and supply 3.7 million people in the southern and southeastern parts of the metropolitan area. Its water temperature measured at 3.3 meters depth varies between $18.7^{\circ} \mathrm{C}$ in winter and $26.5^{\circ} \mathrm{C}$ in summer. Turbidity levels range from average 11.5 NTU (Nephelometric Turbidity Unity) in dry winter to 4 NTU in rainy summer.

It is the most-threatened reservoir among the sources that supply the region, due to its branched, narrow and elongated drainage, formed in the base of the watershed's drainage and in a river valley, favoring anthropic action and occupation. The anthropic pressure on the Guarapiranga Reservoir comes mainly from informal, irregular settlements located on its margins, with poor sanitary and drainage infrastructure, contributing to the eutrophication of this limnological environment and to the proliferation of cyanobacteria.

A study of the taxonomy of its phytoplankton community found that, among the seventeen cyanobacterial taxa identified, described and illustrated, five belong to Chroococcales (29.5\%); two to Synechococcales (11.5\%); two to Oscillatoriales (11.5\%); four to Pseudanabaenales $(23.5 \%)$ and four to Nostocales $(23.5 \%)$ (Rodrigues, 2008). The author emphasizes that, among the identified taxa present in both Billings and Guarapiranga Reservoirs, nine of them are potentially toxic: Microcystis aeruginosa, Microcystis panniformis, Microcystis protocystis, Woronichinia naegeliana, Geitlerinema unigranulatum, Planktothrix agardhii, Planktothrix isothrix, Anabaena circinalis, Cylindrospermopsis raciborskii (Rodrigues, 2008).

In Figure 1 it is possible to identify, in grey-orange color, the urbanized metropolitan region of São Paulo, and how it surrounds the Guarapiranga Reservoir. Protection zone with vegetation cover is limited and transformed in parks, but irregular settlements frequently invade these areas, causing very negative anthropic pressure on this freshwater reservoir.

To verify a possible correlation between cyanobacteria-bloom variations in the Guarapiranga Reservoir and selected meteorological variables, the Linear Regression method was used in the Stepwise format for variable selection.

Cyanobacteria biomass density values were acquired from the Basic Sanitary Company of the State of São Paulo (SABESP, 2016). The cyanobacteria measurements are taken by the company weekly, maintaining an average of 2 to 3 measurements per week at three points. However, only two of them, GU101 and GU104, had monthly data series with uninterrupted cyanobacteria measurements. Limnological parameters were not included in the regression because the aim of our study was to understand the correlations between Cyanobacterial blooms and weather/climate.

In total, 84 observations for the period from 2010 to 2016 were included in this study, organized in monthly average values in order to have a regular pattern and because the process does not follow a daily rhythm. The meteorological variables utilized were: Mean Air Temperature (Tmean), Maximum Mean Air Temperature (Tmax), Absolute Mean Temperature (Tmax_abs), Minimum Mean Air Temperature (Tmin), Absolute Minimum Air Temperature (Tmin_abs), Solar Radiation (Rad), Total Radiation (Rad_tot), Atmospheric Pressure (Press), Total Precipitation (Prec_tot), Precipitation Days (Days_prec), Maximum Daily Precipitation (Prec_day_max), Mean Wind Direction (Wind_dir_mean), Mean Wind Speed (Wind_ave) and Maximum Wind Speed (Wind_max), all monthly. Data was obtained from IAG- Institute of Astronomy and Geophysics of the University of São Paulo Meteorological Station, located at Parque Fontes do Ipiranga, near the Guarapiranga Reservoir.

The cyanobacteria variation data from points GU101 and GU104 did not present a normal distribution (Figure 2). Thus, the $\log _{10}$ calculation was calculeted, given that normality is a premise of regression modelling. In Figure 2, the distribution of the cyanobacteria concentration before the transformation ( $a$ and $b$ ) and after the application of the $\log _{10}(c$ and $d$ ) may be observed. 
a) Histogram GU101

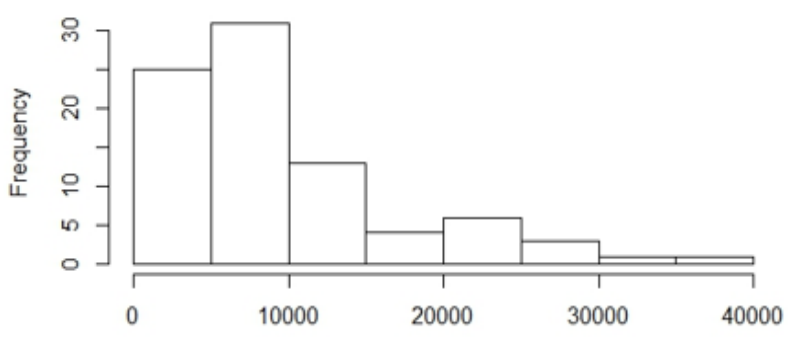

b) Histogram GU104

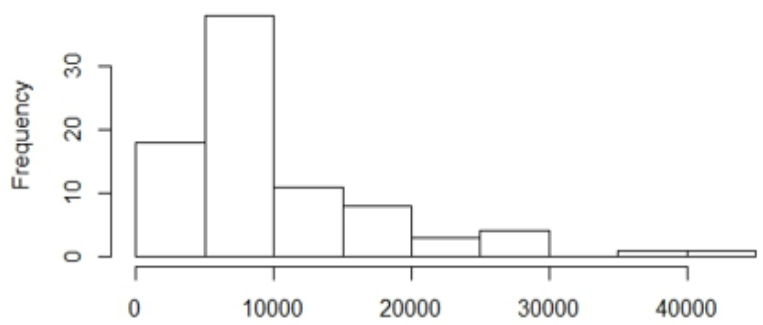

c) Histogram GU101_log

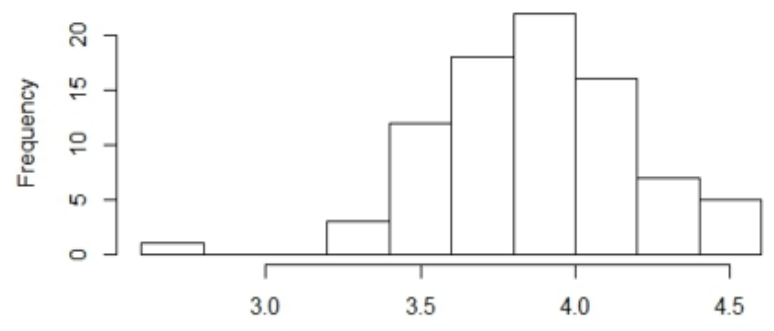

d) Histogram GU104_log

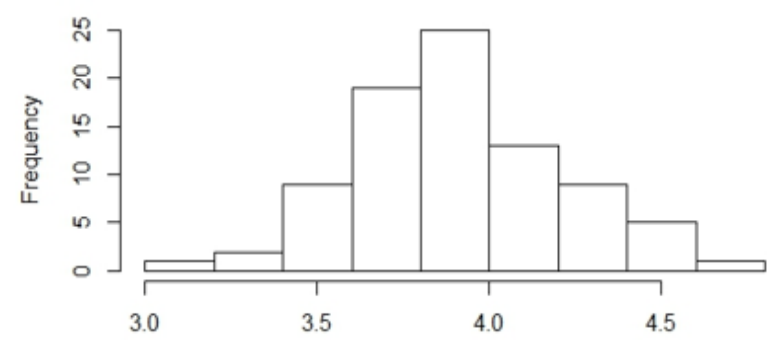

Figure 2. Histograms of the data from collection points GU101 and GU104 before the transformation ( $a$ and $b$ ) and after the application of $\log _{10}(\mathrm{c}$ and $d)$.

\section{RESULTS AND DISCUSSION}

For the study period, Table 1 shows the variability of the variables used. The Maximum Mean Temperature Value for this period was $31.8^{\circ} \mathrm{C}$, the Minimum Mean Temperature was $9.7^{\circ} \mathrm{C}$. The highest cyanobacteria concentrations in the reservoir were $37,740 \mathrm{cel} / \mathrm{mL}$ for collection point GU101 and 40,788.3 cel/mL for point GU104, with a standard deviation of $7,626.4 \mathrm{cel} / \mathrm{mL}$ and 7,814.4 cel/mL, respectively. In the 7-year period, 1,342 days registered precipitation. On average, there were 15 rainy days per month. For the period, the lowest monthly precipitation was $139 \mathrm{~mm}$ and the highest monthly value was $653 \mathrm{~mm}$. The average wind speed of $5.2 \mathrm{~km} / \mathrm{h}$ indicates the predominance of weak winds in the region.

Before creating the regression model, a linear correlation calculation was performed between the variables utilized in the study, including dependent and independent variables (Table 2). The atmospheric variables included in the models showed the highest correlation with the cyanobacteria variations GU104_log and GU101_log, without showing collinearity with other variables of the same nature, as was the case of collinearity between Precipitation with higher Minimum Air Temperature. The Pearson linear correlation was calculated with a statistical significance of $95 \%(\mathrm{p}=0.05)$.

For the reservoir point GU 104log, the variables that had the highest correlation values were: Maximum Air Temperature, Solar Radiation, Total Rain Precipitation, and Average Wind Speed.

To evaluate the influence of meteorological variables on the concentration of cyanobacteria, multiple regression models were made, and to evaluate which had the best performance, the values of AIC, F-statistic, adjusted R2 and p value were analyzed.

For point GU101 (Table 3), the variables that had the highest correlation values were: Solar Radiation, Atmospheric Pressure, Total Rain Precipitation, Wind Direction and Average Wind Speed. 
Table 1. Descriptive table of the data employed in the linear regression.

\begin{tabular}{|c|c|c|c|c|c|c|c|c|c|c|c|c|}
\hline & GU104 & GU104_log & GU101 & GU101_log & Tmax & Tmed & Tmin & Rad & Prec_tot & Days_prec & Wind_dir_ave & Wind_ave \\
\hline Minimum & 1540.1 & 3.1 & 611.7 & 2.7 & 21.3 & 14.5 & 9.7 & 8.5 & 1.8 & 1 & 1 & 2.7 \\
\hline Average & 10269.2 & 3.9 & 9789.2 & 3.8 & 26 & 19.7 & 15.5 & 14.9 & 139.9 & 15.9 & 5.5 & 5.2 \\
\hline Maximum & 40788.3 & 4.6 & 37740 & 4.5 & 31.8 & 24.3 & 19.8 & 22 & 653.2 & 28 & 9 & 6.3 \\
\hline Sum & 862611.3 & 328.2 & 822290.1 & 325.5 & 2186.9 & 1654.3 & 1298.4 & 1258.3 & 11759.1 & 1342 & 468 & 443.4 \\
\hline SD & 7814.4 & 0.3 & 7626.4 & 0.3 & 2.6 & 2.6 & 2.8 & 3 & 116.2 & 5.7 & 2.5 & 0.6 \\
\hline
\end{tabular}

*SD, Standard Deviation.

Table 2. Linear regression matrix of the data variation of cyanobacteria from the Collection points GU101 and GU104 at the Guarapiranga Reservoir and of the meteorological data from IAG.

\begin{tabular}{|c|c|c|c|c|c|c|c|c|c|c|c|c|c|c|c|c|c|c|}
\hline GU104_log & GU104_log & GU101 & GU101_log & Tmean & Tmax & Tmax_abs & Tmin & Tmin_abs & Ampli & $\operatorname{Rad}$ & Rad_tot & Press & Prec_tot & Days_prec & $\begin{array}{l}\text { Prec day } \\
\max \end{array}$ & $\begin{array}{l}\text { Wind } \\
\text { direc } \\
\text { mean }\end{array}$ & $\begin{array}{l}\text { wind } \\
\text { mean }\end{array}$ & $\begin{array}{l}\text { wind } \\
\max \end{array}$ \\
\hline GU101 & 1 & & & & & & & & & & & & & & & & & \\
\hline GU101_log & 0.7 & 1 & & & & & & & & & & & & & & & & \\
\hline Tmean & 0.8 & 0.9 & 1 & & & & & & & & & & & & & & & \\
\hline Tmax & 0.4 & 0.4 & 0.4 & 1 & & & & & & & & & & & & & & \\
\hline Tmax_abs & 0.4 & 0.5 & 0.4 & 1 & 1 & & & & & & & & & & & & & \\
\hline Tmin & 0.4 & 0.5 & 0.4 & 0.8 & 0.8 & 1 & & & & & & & & & & & & \\
\hline Tmin_abs & 0.4 & 0.3 & 0.3 & 1 & 0.9 & 0.7 & 1 & & & & & & & & & & & \\
\hline Ampli & 0.3 & 0.2 & 0.2 & 0.9 & 0.8 & 0.6 & 0.9 & 1 & & & & & & & & & & \\
\hline $\operatorname{Rad}$ & -0.1 & 0 & 0 & -0.6 & -0.4 & -0.3 & -0.6 & -0.8 & 1 & & & & & & & & & \\
\hline Rad_tot & 0.4 & 0.5 & 0.5 & 0.7 & 0.8 & 0.8 & 0.6 & 0.6 & -0.3 & 1 & & & & & & & & \\
\hline Press & 0.4 & 0.5 & 0.5 & 0.7 & 0.8 & 0.8 & 0.6 & 0.5 & -0.3 & 1 & 1 & & & & & & & \\
\hline Prec_tot & -0.3 & -0.3 & -0.3 & -0.8 & -0.7 & -0.7 & -0.8 & -0.7 & 0.4 & -0.7 & -0.6 & 1 & & & & & & \\
\hline Days_prec & 0.1 & 0 & 0.1 & 0.7 & 0.6 & 0.4 & 0.7 & 0.7 & -0.5 & 0.4 & 0.3 & -0.6 & 1 & & & & & \\
\hline Prec day max & 0.1 & 0.1 & 0 & 0.6 & 0.4 & 0.4 & 0.6 & 0.6 & -0.4 & 0.3 & 0.3 & -0.6 & 0.7 & 1 & & & & \\
\hline $\begin{array}{l}\text { wind direc } \\
\text { mean }\end{array}$ & 0.1 & 0 & 0.1 & 0.5 & 0.4 & 0.3 & 0.6 & 0.5 & -0.3 & 0.3 & 0.3 & -0.6 & 0.8 & 0.6 & 1 & & & \\
\hline wind mean & 0.1 & 0.2 & 0.1 & 0 & 0 & 0.1 & 0 & -0.1 & 0.3 & 0.1 & 0.1 & -0.1 & 0 & -0.1 & 0.1 & 1 & & \\
\hline wind max & 0.2 & 0.2 & 0.1 & 0.2 & 0.2 & 0.5 & 0.2 & 0.2 & -0.2 & 0.5 & 0.5 & -0.3 & 0 & 0.3 & 0.1 & -0.1 & 1 & \\
\hline
\end{tabular}


Table 3. Multiple Linear Regression Results for point GU101.

\begin{tabular}{lccccc}
\hline \multicolumn{6}{c}{ GU101_log } \\
\hline & DF & AIC & F-Statistic & $\mathrm{R}^{2}$ Adjusted & $\mathrm{p}$ Value \\
\hline Model 1 & 79 & 1477,335 & 9.669 & 0.2947 & $2.04 \mathrm{E}-06$ \\
Model 1 A & 79 & 1477,147 & 9.735 & 0.2963 & $1.88 \mathrm{E}-06$ \\
Model 2 & 80 & 1476,467 & 12.52 & 0.294 & $8.56 \mathrm{E}-07$ \\
Model 3 & 81 & 1474,478 & 19.01 & 0.3027 & $1.70 \mathrm{E}-07$ \\
Model 4 & 82 & 1476,576 & 32.7 & 0.2767 & $1.66 \mathrm{E}-07$ \\
\hline
\end{tabular}

*DF, Degree of Freedom; AIC Akaike information criterion.

In Model 1, the following meteorological variables were used: Solar Radiation, Total Precipitation, Average Wind Speed, and Thermal Amplitude. This first model explained 29\% of the variation in cyanobacteria biomass in the Guarapiranga Reservoir during the period from 2010 to 2016. The Akaike information criterion (AIC) value was 1,477.335 using 79 degrees of freedom (df). The AIC values served as comparison between the performance and the adjustment of spatial regression models. For the AIC values, the lower they are, the better the model adjustment. This measurement is based on the assumption of normality and a function of probability corresponding to the standard regression model [16]. Following the Stepwise method, variables were removed to find the best adjustment. Model 1A used the variables of Solar Radiation, Total Precipitation, Wind Direction and Pressure. In this model, the adjusted $\mathrm{R}^{2}$ result was the same as the previous model, although the Akaike criterion had improved somewhat $(1,477.147)$ and the degrees of freedom had remained the same. In Model 2, the variables Radiation, Total Precipitation, and Pressure were included. In this model, the adjusted $\mathrm{R}^{2}$ value was also $29 \%$, although the Akaike criterion had decreased to $1,476.467$ with 80 degrees of freedom. In Model 3, the Atmospheric Pressure variable was removed, resulting in an adjusted $\mathrm{R}^{2}$ value of $30 \%$ and an Akaike value of 1,474.478 for 81 degrees of freedom. And lastly, Model 4 considered only the meteorological variable Radiation, obtaining an adjusted $\mathrm{R}^{2}$ of $29 \%$ with an Akaike of 1,476.576 with 82 degrees of freedom.

Thus, Model 3 showed best-fitted values, presenting the lowest Akaike value. The variables radiation and precipitation thus were responsible for explaining $30 \%$ of the monthly cyanobacteria biomass variation between 2010 and 2016 in the Guarapiranga Reservoir.

For correlating meteorological variables with cyanobacteria variation at collection point GU 104 (Table 4), Model 1 was composed of atmospheric variables Solar Radiation, Average Wind Speed and Total Precipitation, for presenting the highest correlation values. In this model, the adjusted $\mathrm{R}^{2}$ result was $14 \%$ and the Akaike criterion was -211.0361 for 80 degrees of freedom.

Table 4. Multiple Linear Regression Results for point GU104.

\begin{tabular}{cccccc}
\hline \multicolumn{6}{c}{ GU104_log } \\
\hline & DF & AIC & F-Statistic & $\mathrm{R}^{2}$ Adjusted & p Value \\
\hline Model 1 & 80 & $-211,0361$ & 5.686 & 0.1448 & $1.40 \mathrm{E}-03$ \\
Model 2 & 81 & $-213,0262$ & 8.63 & 0.1553 & $4.00 \mathrm{E}-04$ \\
Model 3 & 82 & $-214,974$ & 17.41 & 0.1651 & $7.45 \mathrm{E}-05$ \\
\hline
\end{tabular}

*DF, Degree of Freedom; AIC Akaike information criterion.

In Model 2, the variable Precipitation was removed and the adjusted $\mathrm{R}^{2}$ values was $15 \%$ and the Akaike criterion was -213.0262 with 81 degrees of freedom. The better model for the collection point was Model 3, composed only of the variable Solar Radiation, which showed an adjusted $\mathrm{R}^{2}$ result of $16 \%$ with an Akaike criterion of -214.974 and 82 degrees of freedom, 
explaining that $16 \%$ of the cyanobacteria biomass variations at this point are due only to the variation in radiation.

The results of the regression model between cyanobacteria blooms and atmospheric variables indicated that the main atmospheric component that influenced the concentration of cyanobacteria was Radiation, explaining $16 \%$ of bloom occurrence during the study period around GU 104. At point GU 101, Radiation combined with Precipitation explained around $30 \%$ of the cases of cyanobacteria proliferation in the period. The data reinforce results of other studies in which Radiation and Rainfall proved to be important components for the proliferation of toxic algae (Oliveira et al., 2014; Faria et al., 2013; Gil-Gill et al., 2011). Radiation is important for photosynthesis. Rainfall in principle should dilute the contaminants in the water and increase dissolved oxygen (DO). However, in very urbanized neighborhoods without proper street cleaning and waste collection, runoff brings much organic matter into the reservoir, becoming a predisposing factor for cyanobacteria biomass blooms. The same effect is caused by rural lots with use of fertilizers that still exist in the Guarapiranga watershed.

Cyanobacterial blooms occur in reservoirs worldwide, but in greater proportion in areas with poorer sanitary conditions or with inadequate treatment of effluents (Oliver, et al., 2019). Those conditions are the primary cause of cyanobacteria biomass blooms, but radiation and higher temperatures represent important secondary factors. In Poland, summer blooms made shallow reservoirs particularly susceptible to eutrophication (Istvanovics et al., 2014). A study in Recife, Brazil also indicated that blooms occurred in the dry hot season (Oliveira et al., 2014). Besides, cyanobacteria blooms can increase the local temperature of water, due to the intense absorption of light. In China, the main environmental parameter that influenced blooms was water temperature (Zhao et al., 2013; Wu et al. 2017). The summer period was also related to an increase in blooms in China (Xu et al., 1992) and in Poland (Kozak et al., 2017). Another study (Henry and Santos, 2008) indicated that a temperature of $25^{\circ} \mathrm{C}$ was most favorable for the excretion of ammonia and phosphorus by Chironomus larvae, which can be an indicator of increased eutrophication of the reservoir during summer, leading to increase in blooms in the water body. In the State of New York, USA, a larger quantity of algae was found in the fall and summer (Effler et al., 2006). Also, in the northern hemisphere, a larger cyanotoxin biomass volume was detected at the end of fall in Portugal (Morais et al., 2010) and in China (Sun et $a l .$, 2009). At the Guarapiranga watershed, air temperatures are more homogeneous when compared to the watersheds in temperate climates, such as in China and the US. The same applies to water temperature that can be adequate for cyanobacterial biomass growth yearround. On the other hand, this study indicated the influence of radiation and precipitation as important environmental parameters in tropical/subtropical climates.

In our study, the multiple regression model was capable of explaining around $30 \%$ of the algae proliferations. However, it was based on variable data grouped by month. The monthly grouping of data might represent a limitation, because it diminishes the observations available for correlation analyses. Despite this, the study reinforced that toxic algae proliferations in reservoir basins under anthropic pressure, among multifactorial causes, have important meteorological components.

\section{CONCLUSIONS}

There are notable influences of meteorological variables on algae biomass blooms, which may differ depending on the location and on the species studied. These findings enrich findings of former investigations and reinforce the need for further studies regarding the modelling of future scenarios of toxic algae proliferation throughout the world under global warming forecasts and for the evaluation of future health threats. The study also points to the need for global warming prevention and for water pollution control via implementation of adequate sanitary infrastructure and services in subnormal housing settlements, in order to protect the

Rev. Ambient. Água vol. 15 n. 4, e2523 - Taubaté 2020 
aquatic resources that are so crucial for urban development and environmental health.

\section{ACKNOWLEDGEMENTS}

We are grateful to the IAG- Institute of Astronomy and Geophysics of the University of São Paulo Meteorological Station for making the historical meteorological dataset available; and to the Coordination for the Improvement of Higher Education Personnel - Brazil (CAPES) for Doctorate Scholarship.

\section{REFERENCES}

AZEVEDO, S. M. F. O. Toxinas de cianobactérias: causas e consequências para a saúde pública. Revista Virtual de Medicina, v. 1, n. 3, 1998.

CAVAlCANTE, R. R. M. et al. Análise Temporal da Densidade de Cianobactérias de um reservatório de abastecimento humano. In: CONGRESSO DE PESQUISA E INOVAÇÃO DA REDE NORTE E NORDESTE DE EDUCAÇÃO TECNOLÓGICA, 4., 2009, Belém. Anais[...] Belém: Instituto Federal do Pará, 2009.

EFFLER, S. W.; O'DONNELL, D. M.; PENG, F. et al. Use of robotic monitoring to assess turbidity patterns in Onondaga Lake, NY. Lake and Reservoir Management, v. 22, n. 3, p. 199-212, 2006. https://doi.org/10.1080/07438140609353897

ESTEVES, F. A.; SUZUKI, M. S. Comunidade Fitoplanctônica. In: ESTEVES, F. A. (coord.) Fundamentos de Limnologia. Rio de Janeiro: Interciência, 2011. p. 375-377.

FARIA, D. M. de; GUIMARAES, A. T. B.; LUDWIG, T. A. V. Responses of periphytic diatoms to mechanical removal of Pistia stratiotes L. in a hypereutrophic subtropical reservoir: dynamics and tolerance. Brazilian Journal of Biology, v. 73, n. 4, p. 681-689, 2013. http://dx.doi.org/10.1590/S1519-69842013000400002

FONSECA, F. S. et al. Influência de fatores climatológicos na ocorrência de microcistina. Revista do Instituto Adolfo Lutz, v. 69, n. 4, p. 461-466, 2010.

GIJSBERTSEN-ABRAHAMSE, A. J.; SCHMIDT, W.; CHORUS, I.; HEIJMAN, S. G. J. Removal of cyanotoxins by ultrafiltration and nanofiltration. Journal of Membrane Science. v. 276, n. 1-2, p. 252-259, 2005. https://doi.org/10.1016/j.memsci.2005.09.053

GIL-GILL, F.; FERRAGUT, C.; BICUDO, C. E. de M. Do phytoplankton fractions < $20 \mathrm{mu}$ m dominate in tropical reservoirs independent of their trophy? Limnetica, v. 30, n. 1, p. 143-158, 2011.

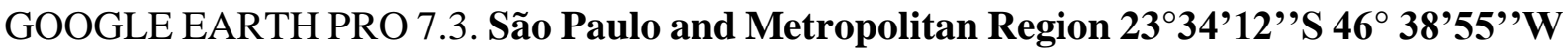
819M. elevation 68km. 3D map, Buildings layer, viewed April 27 2020. Available at https://www.google.com.br/earth/download/gep/agree.html. Access: April 27, 2020.

HENRY, R.; SANTOS, C. M. The importance of excretion by Chironomus larvae on the internal loads of nitrogen and phosphorus in a small eutrophic urban reservoir. Brazilian Journal of Biology. v. 68, n. 2, p. 349-357, 2008. http://dx.doi.org/10.1590/S151969842008000200016

ISTVANOVICS, V.; HONTI, M.; KOVACS, A. Phytoplankton growth in relation to network topology: time-averaged catchment-scale modelling in a large lowland river. Freshwater Biology, v. 59, n.9, p. 1856-1871, 2014. https://doi.org/10.1111/fwb.12388 
KOZAK, A.; GOLDYN, R.; DONDAJEWSKA, R. Changes in Phytoplankton and Water Quality during Sustainable Restoration of an Urban Lake Used for Recreation and Water Supply. Water, v. 9, n. 9, 2017. https://doi.org/10.3390/w9090713

LAMPARELli, M. C. et al. Atlas de cianobactérias da bacia do Alto Tietê. São Paulo: CETESB, 2014.

MORAIS, S. S.; MOLOZZI, J.; VIANA, A. L. Diversity of larvae of littoral Chironomidae (Diptera: Insecta) and their role as bioindicators in urban reservoirs of different trophic levels. Brazilian Journal of Biology. v. 70, n. 4. p. 995-1004, 2010. http://dx.doi.org/10.1590/S1519-69842010000500011

OLIVEIRA, F. H. P. C.; CAPELA E ARA, A. L. S.; MOREIRA, C. H. P. Seasonal changes of water quality in a tropical shallow and eutrophic reservoir in the metropolitan region of Recife (Pernambuco-Brazil). Anais da Academia Brasileira de Ciências, v. 86, n. 4, p. 1863-1872, 2014. https://doi.org/10.1590/0001-3765201420140128

OLIVER, S. L.; CORBURN, J.; RIBEIRO, H. Challenges Regarding Water Quality of Eutrophic Reservoirs in Urban Landscapes: A Mapping Literature Review. International Journal of Environmental Research and Public Health, v. 16, p. 40, 2019. https://doi.org/10.3390/ijerph16010040

OLIVER, S. L.; RIBEIRO, H. Water supply, climate change and health risk factors: example case of São Paulo -Brazil. In: LEAL FILHO, W.; AZEITEIRO, U. M.; ALVES, F. (Org.). Climate Change and Health Improving Resilience and Reducing Risks. 1. ed. Switzerland: Springer, 2015. v. 1. p. 1-480.

PAERL, H. W.; HUISMAN, J. Blooms Like It Hot. Science, v. 320, n. 5872, p. 57-58, 2008. http://dx.doi.org/10.1126/science.1155398

PEDROSA, C. S. G.; SOUZA, L. R. Q.; LIMA, C. V. F.; LEDUR, P. F.; KARMIRIAN, K.; GOMES,T. A.; BARBEITO-ANDRES, J.; COSTA, M. N.; HIGA, L. M.; BELLIO, M.; LARA, F. A.; TANURI, A.; GARCEZ P. P.; PRATA-BARBOSA, A.; TOVAR-MOLL, F.; MOLICA, R. J. R.; REHEN, S. K. The cyanobacterial saxitoxin exacerbates neural cell death and brain malformations induced by Zika virus. BioRxiv, 2019. https://dx.doi.org/10.1101/755066

RAPALA, J.; LAHTI, K..; RASANEN, L. A.; ESALA, A.; NIEMELA, S. I.; SIVONEN, K. Endotoxins associated with cyanobacteria and their removal during drinking water treatment. Water Research, v. 37, p. 2627-2635, 2002. https://doi.org/10.1016/S00431354(01)00478-X

RIBEIRO, P. C. Análise de fatores que influenciam a proliferação de cianobactérias e algas em lagoas de estabilização. 2007. 106p. Dissertação (Mestrado em Engenharia Sanitária e Ambiental) - Centro de Tecnologia e Recursos Naturais, Universidade Federal de Campina Grande, Campina Grande, 2007.

RODRIGUES, L. L. Biodiversidade de cianobactérias e algas das represas Billings (Braço Taquacetuba), e Guarapiranga, SP, Brasil. 2008. Dissertação (Ecologia) Universidade de São Paulo, São Paulo, 2008.

RODRÍGUEZ, E. M. et al. Kinetics of the oxidation of cylindrospermopsin and anatoxin-a with chlorine, monochloramine and permanganate. Water Research, v. 41, p. 2048- 2056, 2007. https://doi.org/10.1016/j.watres.2007.01.033 
SABESP. Monitoramento da Qualidade da Água da Transposição do Braço Taquacetuba (Billings) para a Represa Guarapiranga. 2016. Available at: http://site.sabesp.com.br/site/interna/Default.aspx?secaoId=43. Access: Abril 24, 2020.

SUN, L.; JIN, X. C.; ZHONG, Y. Seasonal Dynamics of Phytoplankton in Relation to Key Aquatic Habitat Factors in a Polluted Urban Small Water Body in Tianjin, China. Bulletin Of Environmental Contamination And Toxicology, v. 82, n. 5, p. 543-548, 2009. https://doi.org/10.1007/s00128-009-9655-2

TEIXEIRA, M. R.; ROSA, M. J. Microcystins removal by nanofiltration membranes. Separation and Purification Technology, n. 46, p. 192-201, 2005. https://doi.org/10.1016/j.seppur.2005.05.013

WHO. Guidelines for drinking-water quality. 4th ed. Geneva, 2011.

WHO. Toxic Cyanobacteria in water: a guide to their public health consequences, monitoring and management. London, 1999.

WU, Q.; QI, J.; XIA, X. Long-term variations in sediment heavy metals of a reservoir with changing trophic states: Implications for the impact of climate change. Science of The $\begin{array}{llllll}\text { Total Environment, } & \text { v. } & 609, & \text { p. }\end{array}$ https://doi.org/10.1016/j.scitotenv.2017.04.041

XU, Z. K. The abundance of epizoic ciliate epistylis-daphniae related to their host Moina Macrocopa in an urban stream. Journal of invertebrate pathology, v. 60, n. 2, p. 197200, 1992. https://doi.org/10.1016/0022-2011(92)90097-N

ZHAO, Z.; MI, T.; XIA, L. Understanding the patterns and mechanisms of urban water ecosystem degradation: phytoplankton community structure and water quality in the Qinhuai River, Nanjing City, China. Environmental Science and Pollution Research, v. 20, n. 7, p. 5003-5012, 2013. https://doi.org/10.1007/s11356-013-1464-9 